\title{
Evaluation of $p$-Hydroxyphenylpyruvate Dioxygenase-inhibiting Herbicides for Controlling Mugwort
}

\author{
William E. Klingeman ${ }^{1,2,7}$, Gregory R. Armel ${ }^{1,3,5}$, Henry P. Wilson ${ }^{2,6}$, \\ Thomas E. Hines ${ }^{4,6}$, Jose J. Vargas ${ }^{1}$, and Philip C. Flanagan ${ }^{1}$
}

Additional index words. Artemisia vulgaris, atrazine, bentazon, clopyralid, false chrysanthemum, HPPD, mesotrione, PSII inhibitor, topramezone

Summary. Mugwort (Artemisia vulgaris) is a perennial invasive weed species that has infiltrated row crops, turfgrass, ornamentals, and various noncrop areas. Currently, multiple mimics of indole-3-acetic acid can provide control of this species; however, these herbicides can damage certain sensitive ornamental plants. When applied at reduced rates, the $p$-hydroxyphenylpyruvate dioxygenase (HPPD)inhibiting herbicides mesotrione and topramezone have demonstrated some selectivity among certain ornamental plants. Field and greenhouse studies were initiated to evaluate whether these herbicides could control mugwort when applied alone, or in mixtures with photosystem II (PSII)-inhibiting herbicides that often provide synergistic weed control. In the field, mesotrione controlled mugwort between $30 \%$ and $60 \%$ by 21 days after treatment when applied at 0.093 to 0.187 $\mathrm{lb} / \mathrm{acre}$. When the PSII-inhibiting herbicide atrazine was added, control increased to $78 \%$ and $79 \%$. In the greenhouse, similar rates produced greater control in mugwort, and all mesotrione treatments limited mugwort regrowth by at least $95 \%$ when compared with untreated control. When HPPD inhibitor rates were reduced further, the addition of the PSII inhibitors atrazine or bentazon was not sufficient at providing acceptable control of mugwort.

$\mathrm{M}$ ugwort or false chrysanthemum is an adaptable, nonnative perennial plant that is a management challenge to commercial agronomic and ornamental crop production worldwide (Barney and DiTommasso, 2003; Henderson and Weller, 1985; Holm et al., 1997; Uva et al., 1997). In the eastern United States, mugwort has expanded beyond ornamental nurseries into turf, pastures, and cropping systems including corn (Zea mays), cotton (Gossypium hirsutum), and soybean (Glycine max) (Bradley and Hagood, 2002a, 2002b; Yelverton et al., 2012).

Mugwort reproduction and dispersal is achieved primarily by transport of rhizome pieces on contaminated cultivation equipment and within soil and soilless substrates around the roots of

${ }^{1}$ Plant Sciences Department, The University of Tennessee Institute of Agriculture, Knoxville, TN 37996

${ }^{2}$ Professor

${ }^{3}$ Assistant Professor

${ }^{4}$ Research Associate

${ }^{5}$ Current address: BASF Corporation, Research Triangle Park, NC 27709

${ }^{6}$ Current address: Eastern Shore Agricultural Research and Extension Center, Virginia Tech, Painter, VA 23420 .

${ }^{7}$ Corresponding author. E-mail: wklingem@utk.edu. crop plants (Barney and DiTommasso, 2003; Bradley and Hagood, 2002a, 2002b; Holm et al., 1997; Rogerson and Bingham, 1964; Uva et al., 1997). In nursery fields, rhizomes are abundant in the upper 4 inches of soil (Pridham, 1963; Rogerson and Bingham, 1964). Tillage will exacerbate localized mugwort infestation because rhizome sections $2-\mathrm{cm}$ long reproduce well when grown in pine bark, sand, and soil substrates (Guncan, 1982; Klingeman et al., 2004; Rogerson et al., 1972).

Postemergence (POST) control of weeds in nursery operations remains a particularly attractive option for both field-grown and container production systems due, in part, to need to reduce labor costs incurred for hand-weeding in addition to the current practice of making about three annual herbicide applications per nursery (Gilliam et al., 1990; Mathers, 1999). Yet, control options for mugwort are limited due in part to challenges presented by herbicide costs, herbicide phytosafety across desirable crop commodities (including turfgrass and ornamentals), and limited efficacy available herbicides may have on other key weed species. For example, ethyl N, $\mathrm{N}$-di-n-propylthiolcarbamate application at $15 \mathrm{lb} /$ acre has controlled mugwort in field nurseries, yet this rate is too high to safely manage mugwort in stands of field corn (Bing and Pridham, $1963,1964)$. Glyphosate is effective on young mugwort plants but is less effective at controlling large mugwort plants in later stages of growth (Ahrens, 1976; Bradley and Hagood, 2002a, 2002b). Plant growth regulating herbicides that mimic indole-3-acetic acid, like 2,4dichlorophenoxyacetic acid and clopyralid, have generally provided poor mugwort control, even at high application rates (Ahrens, 1976; Bingham, 1965; Bradley and Hagood, 2002a, 2002b; Day et al., 1997). Clopyralid can control mugwort and reduce regrowth the following year, yet clopyralid is relatively expensive, has limited efficacy against other commonly encountered weed species, and is challenged by limited crop safety across a diverse assemblage of ornamental plant species (Bradley and Hagood, 2002a, 2002b; Bradley et al., 2000; Day et al., 1997; Koepke-Hill et al., 2011). Still, the broad utility of clopyralid (Stinger ${ }^{\circledR}$ and Transline ${ }^{\circledR}$; Dow AgroSciences, Indianapolis, IN) across corn, sugarbeet (Beta vulgaris), pasture and rangeland, Christmas tree, ornamental plant, and fruit and vegetable crop production systems makes this herbicide a practical choice for selective control of mugwort.

Mesotrione and topramezone impede carotenoid biosynthesis by inhibiting the enzyme $p$-HPPD (Norris et al., 1998). Mesotrione is registered for preemergence (PRE) and POST applications in corn and turfgrass (BASF, 2013; Mitchell et al., 2001;

\begin{tabular}{llll}
\hline $\begin{array}{l}\text { Units } \\
\begin{array}{l}\text { To convert U.S. to SI, } \\
\text { multiply by }\end{array}\end{array}$ & U.S unit & SI unit & $\begin{array}{l}\text { To convert SI to U.S., } \\
\text { multiply by }\end{array}$ \\
\hline 0.3048 & $\mathrm{ft}$ & $\mathrm{m}$ & 3.2808 \\
9.3540 & $\mathrm{gal} / \mathrm{acre}$ & $\mathrm{L} \cdot \mathrm{ha}^{-1}$ & 0.1069 \\
2.54 & inch $(\mathrm{es})$ & $\mathrm{cm}$ & 0.3937 \\
1.1209 & $\mathrm{lb} / \mathrm{acre}$ & $\mathrm{kg} \cdot \mathrm{ha}^{-1}$ & 0.8922 \\
6.8948 & $\mathrm{psi}$ & $\mathrm{kPa}$ & 0.1450
\end{tabular}


Syngenta Crop Protection, 2011, 2012) and provides effective POST control against many annual broadleaf weeds and certain grass species (Armel et al., 2003, 2009; Beckett and Taylor, 2000; Sutton et al., 1999). Topramezone is also registered for POST weed control in corn and turfgrass (e.g., Amvac, 2007; BASF, 2013). Apparent as foliar photobleaching, topramezone reduces total chlorophyll, $\beta$-carotene, lutein, and other xanthophyll cycle pigments in susceptible grassy and broadleaf weeds, including common bermudagrass (Cynodon dactylon), hybrid bermudagrass $(C$. dactylon $\times$ C. transvaalensis), and annual bluegrass (Poa annua) (BASF, 2013; Brosnan et al., 2011; Elmore et al., 2011, 2013).

In limited tests with ornamental plants, some HPPD herbicides have provided acceptable ornamental tolerance at rates that provide some level of weed control (Armel et al., 2009; Elmore et al., 2013; Little et al., 2004; Senesac and Tsontakis-Bradley, 2007; Stamps and Chandler, 2009). Increased POST control of some perennial weed species was achieved when HPPD-inhibiting herbicides, like mesotrione, were combined with other herbicides, especially those that inhibit PSII inhibitors (Bradley et al., 2000; Kaastra et al., 2008). For example, POST mixtures of reduced rates of the PSII inhibitor atrazine plus mesotrione has enhanced management of larger and more difficult to control weed species, including nutsedge (Cyperus sp.) and canada thistle (Cirsium arvense) (Armel et al., 2005, 2008, 2009; Beckett and Taylor, 2000; Johnson and Young, 1999, 2000, 2002; Johnson et al., 2002; Kaastra et al., 2008; Mueller, 2000). Efforts to assess reduced rates of mesotrione and topramezone in mixtures with the PSII inhibitor bentazon, which is one of the few PSII-inhibiting herbicides registered for use in turfgrass and ornamental production systems, revealed some weed control efficacy yet induced moderate phytotoxic injury to foliage and terminals of flowering dogwood (Cornus florida) and Knock Out ${ }^{\mathrm{TM}}$ rose (Rosa sp. 'Radrazz'). Still, trials revealed acceptable plant safety for treatments applied to ornamental cultivars of woody japanese holly (Ilex crenata), burning bush (Euonymus alatus), weigela
(Weigela florida), spiraea (Spiraea japonica), arborvitae (Thuja plicata), herbaceous daylily (Hemerocallis), hosta (Hosta), autumn fern (Dryopteris erythrosora), and pachysandra (Pachysandra terminalis) (Cutulle et al., 2013b).

Few selective weed control options are available for mugwort control, and it generally is not adequately controlled with single applications or reduced rates of POST herbicides (Bradley and Hagood 2002a, 2002b). It follows that synergistic mixtures of reduced rates of HPPD and PSII inhibitors could optimize weed control and increase herbicide tolerance to turfgrass and ornamental crops (Cutulle et al., 2013b). Therefore, objectives of this research were to evaluate low rates of the HPPD herbicide mesotrione and to assess control efficacy of mesotrione combined with known synergist like the PSII inhibitor atrazine for enhanced activity on mugwort compared against the standard clopyralid. The second objective was to quantify the ability of reduced rates of multiple HPPDinhibiting herbicides, either alone or paired with the PSII-inhibiting herbicides atrazine or bentazon, to provide commercially acceptable mugwort control for ornamental plant producers, whether growing in container or field systems.

\section{Materials and methods}

Field EXPERIMENTS. Mugwort experiments were conducted on a government right-of-way near Birds Nest, VA, in 2000. Treatments were calculated as the active ingredient equivalent from formulated products and included $0.093,0.125$, and 0.187 $\mathrm{lb} /$ acre of mesotrione (Callisto ${ }^{\circledR}$; Syngenta Crop Protection, Greensboro, NC) and mesotrione plus atrazine $(0.093 \mathrm{lb} /$ acre plus $0.250 \mathrm{lb} / \mathrm{acre})$ that were compared with $0.500 \mathrm{lb} /$ acre clopyralid (Stinger). Applications for the first experimental run were made on 25 July 2000 and repeated in time at an adjacent field site on 29 Aug. 2000. Treatments were applied using a backpack sprayer at $23.0 \mathrm{gal} / \mathrm{acre}$ with a pressure of 23 psi. Four flat fan nozzles (8003; TeeJet Technologies, Wheaton, IL) spaced at 20 -inch intervals. Applications were made to mugwort plants 0.8 to 9.1 inches tall. Soil type at this location was a Bojac sandy loam (coarse-loamy, mixed, semiactive, thermic Typic Hapludult).
All treatments contained $1 \%(\mathrm{v} / \mathrm{v})$ crop oil concentrate [COC (Agridex; Helena Chemical, Memphis, TN)] and 2.5\% (v/v) urea ammonium nitrate (UAN) solution. Experimental plots were $8.3 \mathrm{ft}$ wide by $20 \mathrm{ft}$ long and were arranged in a randomized complete block (RCB) design with three replicates. Mugwort control was assessed visually at 7,14 , and $21 \mathrm{~d}$ after treatment (DAT) using a $0 \%$ to $100 \%$ scale, where $0 \%$ represented no mugwort control and $100 \%$ represented complete mugwort necrosis. Following a land manager decision to mow experimental field plots in advance of right-of-way remediation efforts, field trials were ended before regrowth data could be taken. An alternative site with sufficient contiguous mugwort infestation could not be found to repeat and extend the field trial component.

Greenhouse experiments. Greenhouse experiments in Virginia were initiated in 2001 to evaluate mugwort control using previously field-tested rates of mesotrione $(0.093$, 0.125 , and $0.187 \mathrm{lb} / \mathrm{acre})$, and the lowest mesotrione rate plus a low atrazine rate $(0.250 \mathrm{lb} /$ acre $)$, with efficacy evaluated against the clopyralid herbicide standard. Five 1-inchlong mugwort rhizomes were planted into 4-inch square pots (TO Plastics, Virginia Beach, VA) filled with commercial potting mix (Pro-Mix BX; Premier Horticulture, Red Hill, PA). As needed, plants were watered and fertilized with a $150 \mathrm{ppm}$ nitrogen $(\mathrm{N})$ solution using $21 \mathrm{~N}-2.2 \mathrm{P}-41.5 \mathrm{~K}$ fertilizer (Excel All Purpose; Wetzel, Virginia Beach, VA) to facilitate maximum plant growth and vigor. In 2001, herbicides were applied using a cabinet sprayer at $24 \mathrm{gal} /$ acre with a pressure of 42 psi. A single even flow nozzle (8002; TeeJet Technologies) was placed $30 \mathrm{~cm}$ above the highest part of the treated plants. All treatments contained $1 \%(\mathrm{v} / \mathrm{v})$ COC (Agridex) and $2.5 \%(\mathrm{v} / \mathrm{v})$ UAN solution. Mugwort control was rated visually at 7,14 , and 28 DAT. On 28 DAT, mugwort shoot heights were measured, and then shoots were cut to the soil line, dried and weighed. Mugwort regrowth was quantified again via dry weight measurements from additional shoots excised on 42 DAT.

In 2008, a second series of greenhouse experiments were conducted and repeated in time at the University of Tennessee campus in 
Knoxville. For these trials, mesotrione (Callisto ${ }^{\circledR}$ ) was again tested for its efficacy on mugwort, both alone at a reduced rate $(0.062 \mathrm{lb} /$ acre) selected to assess phytosafety to ornamental plants, and also in combination with atrazine $(0.500 \mathrm{lb} /$ acre) and bentazon ( $0.500 \mathrm{lb} /$ acre $)$. Mugwort control achieved by these two combination herbicides alone was also assessed. Also in 2008, topramezone $\left(\right.$ Impact $^{\circledR} ;$ Amvac, Los Angeles, CA) was included in tests as a second HPPD-inhibiting herbicide at a $0.010 \mathrm{lb} /$ acre rate, both alone and in combination with the same atrazine and bentazon rates used with mesotrione mixes.

In 2008 greenhouse trials, five 1-inch-long mugwort rhizomes were transplanted into 4 -inch pots. The soilless potting substrate was replaced with a Sequatchie loam field soil (Fine-loamy, siliceous, semiactive, thermic humic Hapludult), with 6.2 soil $\mathrm{pH}$ and $2.1 \%$ organic matter content mixed in a $3: 1$ ratio of soil to clay-based soil conditioner (Turface MVP; Turface Athletics, Buffalo Grove, IL), to facilitate water drainage. Treatments were arranged in a RCB design with four replicated blocks of pots. Each treatment also included methylated seed oil surfactant (Methylated Soybean Oil Plus; Universal Crop Protection Alliance, Eagan, $\mathrm{MN})$ at a rate of $1 \%(\mathrm{v} / \mathrm{v})$. Herbicide treatments were applied on 11 Apr. 2008 with a carbon dioxide $\left(\mathrm{CO}_{2}\right)$-pressurized backpack sprayer calibrated at $23 \mathrm{gal} /$ acre. Visual ratings of mugwort control were made 7,14 , and 28 DAT. Mugwort shoot heights were measured 28 DAT; after these data were collected, shoots were cut to the soil line, dried, and weighed. Mugwort regrowth was quantified via dry weight measurements from additional shoot excisions taken 56 DAT.

Herbicide rates tested in both field and greenhouse trials represent the low labeled rate or reductions to the lowest labeled rated in pounds of active ingredient per acre for topramezone and mesotrione in corn and fine turf, with comparison with the labeled rates of atrazine, clopyralid, and bentazon. Arcsine square root transformations were applied to statistical analyses of visual weed control data, and nontransformed data are presented. Analysis of variance was applied to all data and Fisher's least significant difference test $(P \leq 0.05)$ was used for mean separation using the general linear model procedure of SAS (version 9.3; SAS Institute, Cary, NC).

\section{Results and discussion}

Field experiments. Mugwort responses to treatments applied in the field differed across time, thus results from in-time repetitions could not be pooled. By 14 DAT, the low rate of mesotrione plus atrazine treatment controlled $73 \%$ of the mugwort following the July applications. However, this treatment achieved just $51 \%$ mugwort control following August treatments on 14 DAT compared with the clopyralid treatment that was controlling $78 \%$ of mugwort. By 21 DAT in both field trials, mugwort control with mesotrione plus atrazine and clopyralid treatments was $\geq 79 \%$. When applied alone, clopyralid controlled mugwort $84 \%$ to $91 \%$ (Table 1 ).

GreENHOUSE EXPERIMENTS. Results from greenhouse trials repeated in time in VA were consistent by treatment regardless of measured parameter $[F=0.16$ to $0.79 ; \mathrm{df}$ (numerator, denominator) $=5,12$; $P=0.97$ to 0.57$]$; thus data from repeated trials were pooled for reported analyses. Mesotrione alone only provided $30 \%$ control of mugwort, regardless of rate, by $7 \mathrm{DAT}$. When $0.093 \mathrm{lb} /$ acre mesotrione was mixed with $0.250 \mathrm{lb} /$ acre atrazine, rapid mugwort control was observed that exceeded $80 \%$. Mugwort control improved through 28 DAT and all treatments achieved greater than $70 \%$ control of mugwort. Mesotrione rate with atrazine provided $98 \%$ mugwort control, equivalent to clopyralid ( $\mathrm{Ta}-$ ble 2). Plant height and dry weight measurements among all treated mugwort plants still surviving at 28 DAT were reduced compared with untreated control plants $(F=3.97$ to $3.72 ; \mathrm{df}=4,10 ; P \leq 0.026$ to $\leq 0.029)$. Limited regrowth from treated mugwort plants was also evident at 42 DAT. Plants that received the lowest rate of mesotrione had recovered just $5 \%$ of growth (as dry weight) demonstrated through comparison with untreated control plants (Table 2).

Moderate mugwort control was achieved with mesotrione alone at reduced rates and also when combined

Table 1. Mugwort control following experimental treatments in Bird's Nest, VA that were applied along a mugwort-infested roadside and repeated in time in 2000. All herbicide treatments included $1 \%(\mathrm{v} / \mathrm{v})$ crop oil concentrate [COC (Agridex; Helena Chemical, Memphis, TN)] and 2.5\% (v/v) urea ammonium nitrate.

\begin{tabular}{|c|c|c|c|c|}
\hline \multirow[b]{3}{*}{ Treatment } & \multirow[b]{3}{*}{ Rate $(\text { lb /acre })^{\mathrm{z}}$} & \multicolumn{3}{|c|}{ Days after treatment } \\
\hline & & 7 & 14 & 21 \\
\hline & & \multicolumn{3}{|c|}{ Weed control $(\%)^{\mathrm{y}}$} \\
\hline & & \multicolumn{3}{|c|}{25 July } \\
\hline Clopyralid & 0.500 & 38 & $57 b^{x}$ & $91 \mathrm{a}$ \\
\hline Mesotrione & 0.093 & 30 & $41 \mathrm{c}$ & $32 \mathrm{e}$ \\
\hline Mesotrione & 0.125 & 33 & $41 \mathrm{c}$ & $52 \mathrm{~d}$ \\
\hline Mesotrione & 0.187 & 35 & $58 \mathrm{~b}$ & $60 \mathrm{c}$ \\
\hline Mesotrione + & 0.093 & & & \\
\hline Atrazine & 0.250 & 45 & $73 \mathrm{a}$ & $79 \mathrm{~b}$ \\
\hline \multirow[t]{2}{*}{ Untreated control } & 0 & 0 & $0 \mathrm{~d}$ & $0 \mathrm{f}$ \\
\hline & & \multicolumn{3}{|c|}{29 Aug. } \\
\hline Clopyralid & 0.500 & $25 \mathrm{a}$ & $78 \mathrm{a}$ & $85 \mathrm{a}$ \\
\hline Mesotrione & 0.093 & $13 \mathrm{~d}$ & $55 \mathrm{~b}$ & $55 \mathrm{~b}$ \\
\hline Mesotrione & 0.125 & $16 \mathrm{~cd}$ & $46 \mathrm{~b}$ & $48 \mathrm{~b}$ \\
\hline Mesotrione & 0.187 & $18 \mathrm{bc}$ & $48 \mathrm{~b}$ & $53 \mathrm{~b}$ \\
\hline Mesotrione + & 0.093 & & & \\
\hline Atrazine & 0.250 & $22 \mathrm{ab}$ & $5 \mathrm{lb}$ & $78 \mathrm{a}$ \\
\hline Untreated control & - & $0 \mathrm{e}$ & $0 \mathrm{c}$ & $0 \mathrm{c}$ \\
\hline
\end{tabular}


with atrazine and clopyralid, yet these application rates may still result in unacceptable aesthetic injury when trying to achieve POST control by applications made over the top of select ornamental plants (Cutulle et al., 2013a, 2013b; Hester et al., 2011; Little et al., 2004; Senesac and Tsontakis-Bradley, 2007).

Mesotrione rates were also reduced a further $30 \%$ and reassessed in Tennessee greenhouse trials alone and in combination with photosynthesisinhibiting bentazon and atrazine herbicides, to determine if ornamental injury could be reduced. Results of Tennessee greenhouse experiments were consistent across treatments for all measured parameters when repeated in time $(F=2.00$ to $0.25 ; \mathrm{df}=8,35$; $P=0.08$ to 0.98$)$. Therefore, data from repeated trials were pooled for reported analyses. Reduced mesotrione and topramezone rates, at 0.062 and $0.010 \mathrm{lb} /$ acre, respectively, failed to provide adequate control of mugwort $(<21 \%)$ by 28 DAT. Atrazine and bentazon herbicides applied alone provided $<24 \%$ mugwort control. By 28 DAT, mesotrione plus atrazine offered the highest levels of mugwort control, yet no treatment surpassed 37\% control (Table 3). Several treatments slowed mugwort regrowth between 28 and 56 DAT, with mugwort plants treated with mesotrione plus atrazine achieving just 66\% of the regrowth potential demonstrated by untreated control plants (Table 3 ).

\section{Conclusions}

Currently, few POST herbicides are labeled for mugwort control in ornamental crop systems and noncropland areas. From this research, we conclude that moderate rates of mesotrione $(0.093 \mathrm{lb} /$ acre $)$ in mixtures with certain PSII-inhibiting herbicides can provide a viable field management alternative for shortterm, burn-down control of mugwort compared with clopyralid application. However, the rate of mesotrione and the type of PSII-inhibiting herbicide needed severely limit the practicality of this use with some sensitive ornamental plant species. Mugwort regrowth by 56 DAT in the Tennessee greenhouse trials suggest that field studies

Table 2. Mugwort control in 2001 Virginia greenhouse trials in which herbicide treatments were applied to container-grown mugwort plants in a soilless rooting substrate with experiments that were repeated in time. All herbicide treatments included $1 \%(v / v)$ crop oil concentrate (Agridex; Helena Chemical, Memphis, TN) and 2.5\% (v/v) urea ammonium nitrate.

\begin{tabular}{|c|c|c|c|c|c|c|c|}
\hline \multirow[b]{3}{*}{ Treatment } & \multirow[b]{3}{*}{ Rate $(\mathrm{lb} / \text { acre })^{\mathrm{z}}$} & \multicolumn{3}{|c|}{ Days after treatment } & \multirow{3}{*}{$\begin{array}{c}\text { Dry wt } \\
\text { (Percent of control) }\end{array}$} & \multirow{3}{*}{$\begin{array}{l}\text { Ht (Percent } \\
\text { of control) }\end{array}$} & \multirow{3}{*}{$\begin{array}{l}\text { Dry wt regrowth } \\
\text { (Percent of control) }\end{array}$} \\
\hline & & 7 & 14 & 28 & & & \\
\hline & & \multicolumn{3}{|c|}{ Weed control $(\%)^{\mathrm{y}}$} & & & \\
\hline Mesotrione & 0.093 & $28 \mathrm{c}$ & $42 \mathrm{c}$ & $72 \mathrm{c}$ & $36 a$ & $19 \mathrm{a}$ & 5 \\
\hline Mesotrione & 0.125 & $31 \mathrm{c}$ & $68 \mathrm{~b}$ & $87 \mathrm{~b}$ & $24 \mathrm{bc}$ & $5 \mathrm{~b}$ & 1 \\
\hline Mesotrione & 0.187 & $30 \mathrm{c}$ & $62 \mathrm{bc}$ & $88 \mathrm{~b}$ & $28 \mathrm{ab}$ & $9 \mathrm{ab}$ & 2 \\
\hline Untreated control & - & $0 \mathrm{~d}$ & $0 \mathrm{~d}$ & $0 \mathrm{~d}$ & - & - & - \\
\hline
\end{tabular}

${ }^{\mathrm{z}} \mathrm{l} \mathrm{lb} / \mathrm{acre}=1.1209 \mathrm{~kg} \cdot \mathrm{ha}^{-1}$.

${ }^{y}$ Control was evaluated visually on a $0 \%$ (no control) to $100 \%$ (complete necrosis) scale relative to the untreated control.

'Within column means represent nontransformed data. Means followed by different letters are significantly different from untreated checks by Fisher's least significant difference tests of arcsine-transformed values at $P \leq 0.05$.

Table 3. Mugwort control in 2008 Tennessee greenhouse trials in which herbicide treatments were applied to containergrown mugwort plants with experiments that were repeated in time. Mugwort was planted into a soil-based rooting mix that included 3:1 ratio of soil to clay-based soil conditioner (Turface MVP; Turface Athletics, Buffalo Grove, IL). Treatments were applied with a $1 \%$ rate $(v / v)$ of methylated seed oil surfactant (Methylated Soybean Oil Plus; Universal Crop Protection Alliance, Eagan, MN).

\begin{tabular}{|c|c|c|c|c|c|c|}
\hline \multirow[b]{2}{*}{ Treatment } & \multirow[b]{2}{*}{ Rate $(1 \mathrm{~b} / \text { acre })^{\mathrm{z}}$} & \multicolumn{3}{|c|}{ Days after treatment } & \multirow{2}{*}{$\begin{array}{c}\text { Dry wt } \\
\text { (Percent of control) }\end{array}$} & \multirow{2}{*}{$\begin{array}{l}\text { Dry wt regrowth } \\
\text { (Percent of control) }\end{array}$} \\
\hline & & 7 & 14 & 28 & & \\
\hline Atrazine & 0.500 & $6 \mathrm{~b}^{\mathrm{y}}$ & $12 \mathrm{c}$ & $24 \mathrm{bc}$ & $66 \mathrm{c}$ & $96 \mathrm{ab}$ \\
\hline Mesotrione & 0.062 & $11 \mathrm{ab}$ & $21 \mathrm{abc}$ & $21 \mathrm{~cd}$ & $71 \mathrm{bc}$ & $106 a$ \\
\hline Topramezone & 0.010 & $11 \mathrm{ab}$ & $14 \mathrm{bc}$ & $7 \mathrm{e}$ & $92 \mathrm{a}$ & $114 \mathrm{a}$ \\
\hline Mesotrione + & 0.062 & & & & & \\
\hline bentazon & 0.500 & $13 \mathrm{ab}$ & $27 \mathrm{ab}$ & $24 \mathrm{bc}$ & $74 \mathrm{bc}$ & $92 \mathrm{ab}$ \\
\hline Topramezone + & 0.010 & & & & & \\
\hline atrazine & 0.500 & $14 \mathrm{ab}$ & $23 \mathrm{abc}$ & $32 \mathrm{ab}$ & $64 c$ & $74 \mathrm{bc}$ \\
\hline Topramezone + & 0.010 & & & & & \\
\hline bentazon & 0.500 & $13 \mathrm{ab}$ & $23 \mathrm{abc}$ & $14 \mathrm{~d}$ & $88 \mathrm{ab}$ & $111 \mathrm{a}$ \\
\hline
\end{tabular}

${ }^{2}$ Treatments rates are expressed in pounds per acre; $1 \mathrm{lb} /$ acre $=1.1209 \mathrm{~kg} \cdot \mathrm{ha}^{-1}$.

'Within column means represent nontransformed data. Means followed by different letters are significantly different from untreated checks by Fisher's least significant difference tests of arcsine-transformed values at $P \leq 0.05$. 
with extended durations should be evaluated, in conjunction with repeated applications. Regardless, other HPPD- and PSII-inhibiting herbicides should be evaluated for mugwort control and then those mixtures determined to be effective should be studied further for tolerance among multiple ornamental plant species. In addition for container nursery production systems, it may be advantageous to assess benefits of multiple applications of reduced rate HPPD plus PSII inhibitor mixtures that could achieve mugwort control while offering better safety to ornamental plants (e.g., Cutulle et al., 2013a) and other desirable crops not grown in field operations. When applied sequentially, for example, a mixture of topramezone plus the pyridine herbicide triclopyr successfully and safely removed common bermudagrass from desirable turf tall fescue [Lolium arundinaceum (Brosnan and Breeden, 2013)].

\section{Literature cited}

Ahrens, J.F. 1976. Chemical control of Artemesia vulgaris in ornamentals. Proc. Northeastern Weed Sci. Soc. 30:303-307 (abstr.).

Amvac. 2007. Impact herbicide label. Amvac, Los Angeles, CA.

Armel, G.R., G.J. Hall, H.P. Wilson, and N. Cullen. 2005. Mesotrione plus atrazine mixtures for control of canada thistle ( $\mathrm{Cir}$ sium arvense). Weed Sci. 53:202-211.

Armel, G.R., W.E. Klingeman, P.C. Flanagan, and M. Halcomb. 2009. Ornamental plant safety and herbicidal efficacy following use of select combinations of HPPD and PSII inhibitors. Proc. Southern Nursery Assn. Res. Conf. 54:134-138.

Armel, G.R., H.P. Wilson, R.J. Richardson, and T.E. Hines. 2003. Mesotrione combinations for postemergence control of horsenettle (Solanum carolinense) in corn (Zea mays). Weed Technol. 17:65-72.

Armel, G.R., H.P. Wilson, R.J. Richardson, C.M. Whaley, and T.E. Hines. 2008. Mesotrione combinations with atrazine and bentazon for yellow and purple nutsedge (Cyperus esculentus and C. rotun$d u s)$ control in corn. Weed Technol. 22:391-396.

Barney, J.N. and A. DiTommaso. 2003. The biology of Canadian weeds. 118. Artemisia pulgaris L. Can. J. Plant Sci. 83:205-215.

BASF. 2013. Pylex herbicide label. BASF Corp., Research Triangle Park, NC.
Beckett, T.H. and S.E. Taylor. 2000. Postemergence performance of mesotrione in weed control programs. Proc. North Central Weed Sci. Soc. 55:81 (abstr.).

Bing, A. and A.M.S. Pridham. 1963. Field trials for control of Artemisia vulgaris L. Proc. Northeastern Weed Control Conf. 17:202-203.

Bing, A. and A.M.S. Pridham. 1964. The use of EPTC for control of Artemisia vulgaris L. Proc. Northeastern Weed Control Conf. 18:242-244.

Bingham, S.W. 1965. Chemical control of mugwort. Weeds 13:239-242.

Bradley, K.W. and E.S. Hagood, Jr. 2002a. Evaluation of selected herbicides and rates for long-term mugwort (Artemisia vulgaris) control. Weed Technol. 16:164-170.

Bradley, K.W. and E.S. Hagood, Jr. 2002 b. Influence of sequential herbicide treatment, herbicide application timing, and mowing on mugwort (Artemisia vulgaris) control. Weed Technol. 16:346-352.

Bradley, K.W., P. Davis, S.R. King, and E.S. Hagood. 2000. Trumpetcreeper, honeyvine milkweed, and hemp dogbane control with postemergence corn herbicides. Proc. Northeastern Weed Sci. Soc. 54:59 (abstr.).

Brosnan, J.T. and G.K. Breeden. 2013. Bermudagrass (Cynodon dactylon) control with topramezone and triclopyr. Weed Technol. 27:138-142.

Brosnan, J.T., D.A. Kopsell, M.T. Elmore, and G.K. Breeden. 2011. Changes in 'Riviera' bermudagrass [ Cynodon dactylon (L.) Pers.] carotenoid pigments after treatment with three $p$-hydroxyphenylpyruvate dioxygenaseinhibiting herbicides. HortScience 46: 493-498.

Cutulle, M.A., G.R. Armel, J.T. Brosnan, D.A. Kopsell, J.J. Vargas, and W.E. Klingeman. 2013a. Evaluation of HPPD-inhibiting herbicides for weed control in ornamental species. Proc. Southern Weed Sci. Soc. 66:260 (abstr.).

Cutulle, M.A., G.R. Armel, J.T. Brosnan, D.A. Kopsell, W.E. Klingeman, P.C. Flanagan, G.K. Breeden, J.J. Vargas, R. Koepke-Hill, and M.A. Halcomb. 2013b. Evaluation of container ornamental species tolerance to three $p$-hydroxyphenylpyruvate dioxygenase-inhibiting herbicides. HortTechnology 23:319-324.

Day, M.Y., E.S. Hagood, and S.M. Johnson. 1997. Evaluation of herbicide programs for mugwort control in com. Proc. Northeastern Weed Sci. Soc. 51:34 (abstr.).
Elmore, M.T., J.T. Brosnan, G.K. Breeden, and A.J. Patton. 2013. Mesotrione, topramezone, and amicarbazone combinations for postemergence annual bluegrass ( $P o a$ annua) control. Weed Technol. 27:596603.

Elmore, M.T., J.T. Brosnan, D.A. Kopsell, and G.K. Breeden. 2011. Methods of assessing bermudagrass responses to HPPD-inhibiting herbicides. Crop Sci. 51:2840-2845.

Gilliam, C.H., W.J. Foster, J.L. Adrain, and R.L. Shumack. 1990. A survey of weed control costs and strategies in container production nurseries. J. Environ. Hort. 8:133-135.

Guncan, A. 1982. Artemisia vulgaris: Its biological control in tea and hazelnut plantations in Turkey. Attaturk Univ. Proj. No. TOAG-276.

Henderson, J.C. and S.C. Weller. 1985. Biology and control of Artemisia vulgaris. Proc. North Central Weed Control Conf. 40:100-101.

Hester, K., C.L. Palmer, and E. Vea. 2011. IR-4 Ornamental horticulture program mesotrione crop safety. 27 Mar. 2014. <http://ir4.rutgers.edu/Ornamental/ SummaryReports/MesotrioneDataSummary 2011.pdf .

Holm, L., J. Doll, E. Holm, J. Pancho, and J. Herberger. 1997. World weeds: Natural histories and distribution. Wiley, New York, NY.

Johnson, B.C. and B.G. Young. 1999. Effect of postemergence application rate and timing of ZA 1296 on weed control and com response. Proc. North Central Weed Sci. Soc. 54:67 (abstr.).

Johnson, B.C. and B.G. Young. 2000. Effect of postemergence rate and timing of ZA 1296. Proc. North Central Weed Sci. Soc. 55:9 (abstr.).

Johnson, B.C. and B.G. Young. 2002. Influence of temperature and relative humidity on the foliar activity of mesotrione. Weed Sci. 50:157-161.

Johnson, B.C., B.G. Young, and J.L. Matthews. 2002. Effect of postemergence application rate and timing of mesotrione on corn (Zea mays) response and weed control. Weed Technol. 16:414-420.

Kaastra, A.C., C.J. Swanton, F.J. Tardif, and P.H. Sikema. 2008. Two-way performance interactions among $p$-hydroxyphenylpyruvate dioxygenase- and acetolactate synthaseinhibiting herbicides. Weed Sci. 56:841851 .

Klingeman, W.E., D.K. Robinson, and G.L. McDaniel. 2004. Regeneration of mugwort (Artemisia vulgaris) from rhizome sections in sand, pine bark, and soil 


\section{Research Reports}

substrates. J. Environ. Hort. 22:139143.

Koepke-Hill, R.M., G.R. Armel, W.E. Klingeman, M.A. Halcomb, J.J. Vargas, and P.C. Flanagan. 2011. Mugwort control in an abandoned nursery using herbicides that mimic indole-3-acetic acid. HortTechnology 21:558-562.

Little, D.A., R.J. Richardson, and B.H. Zandstra. 2004. Response of four ornamental crops and selected weeds to mesotrione. Proc. North Central Weed Sci. Soc. 59:159 (abstr.).

Mathers, H. 1999. Weed control in container nurseries. Digger 43:36-37.

Mitchell, G., D.W. Bartlett, T.E. Fraser, T.R. Hawkes, D.C. Holt, J.K. Townson, and R.A. Wichert. 2001. Mesotrione: A new selective herbicide for use in maize. Pest Mgt. Sci. 57:120-128.

Mueller, T.C. 2000. ZA 1296: A new mode of action for weed control in com. Proc. Southern Weed Sci. Soc. 53:1 (abstr.).

Norris, S.R., X. Shen, and D. Della Penna. 1998. Complementation of the arabidopsis $p d s 1$ mutant with the gene encoding p-hydroxyphenylpyruvate dioxygenase. Plant Physiol. 117:1317-1323.

Pridham, A.M.S. 1963. Propagation of Artemisia vulgaris from stem cuttings for herbicide test purposes. Proc. Northeastern Weed Control Conf.17, p. 332 (abstr.).

Rogerson, A.B. and S.W. Bingham. 1964. A growth study and seasonal characteristics of Artemisia vulgaris L. Proc. Southern Weed Sci. Soc. 17:360-363.

Rogerson, A.B., S.W. Bingham, C.L. Foy, and J.P. Sterrett. 1972. Influence of fenac on anatomy and carbohydrate reserves in mugwort rhizomes. Weed Sci. 20:445449.

Senesac, A.F. and I. Tsontakis-Bradley. 2007. Phytotoxicity of spray and granular mesotrione to ornamentals. 5 Nov. 2014. <http://www.longislandhort.cornell.edu/ pdfs /2007_annual_reports/6_2007_ research_summaries.pdf $>$.

Stamps, R.H. and A.L. Chandler. 2009. Phytotoxicity of granular formulations of mesotrione, pendimethalin + dimethenamid-
$P$ and sulfentrazone to six wildflowers. Proc. Southern Nursery Assn. Res. Conf. 54:145-151.

Sutton, P.B., G.A. Foxon, J.M. Beaud, J. Anderdon, and R. Wichert. 1999. Integrated weed management systems for maize using mesotrione, nicosulfuron, and acetochlor. Proc. Brit. Crop Protection Conf. 1:225-230.

Syngenta Crop Protection. 2011. Tenacity herbicide label. Syngenta Crop Protection, Inc., Greensboro, NC.

Syngenta Crop Protection. 2012. Callisto herbicide label. Syngenta Crop Protection, Inc., Greensboro, NC.

Uva, R.H., J.C. Neal, and J.M. DiTomaso. 1997. Weeds of the northeast. Cornell Univ. Press, Ithaca, NY.

Yelverton, F., B.R. Lassiter, G.G. Wilkerson, L. Warren, T. Gannon, J.H. Reynolds, and G.S. Buol. 2012. Turf and weed identification: Mugwort [Artemisia vulgaris L.]. 5 Nov. 2014. <http://www.turffiles. ncsu.edu/Weeds/Default.aspx\#IS004136>. 